\title{
BEZWARUNKOWY DOCHÓD PODSTAWOWY JAKO INSTRUMENT OGRANICZENIA NIERÓWNOŚCI DOCHODOWYCH
}

\section{WPROWADZENIE}

W ciagu ostatnich kilkunastu lat nastapiło w gospodarce światowej istotne przyspieszenie postępu technologicznego, czego skutkiem jest coraz szersze zastępowanie pracy ludzkiej nowoczesnymi maszynami i urządzeniami technicznymi. Szacunki naukowców z Uniwersytetu w Oksfordzie (Carl Frey i Michael Osborne) wskazuja, że około 47\% miejsc pracy w Stanach Zjednoczonych jest narażonych na wysokie ryzyko komputeryzacji. Podobnie australijskie opracowanie opublikowane przez Komitet ds. Rozwoju Gospodarczego Australii (CEDA) wskazuje, że około 40\% miejsc pracy w Australii jest narażonych na wysokie ryzyko skomputeryzowania lub zautomatyzowania w ciagu najbliższych $10-15$ lat $^{1}$.

W związku z tym rosną obawy dotyczące przyszłości zatrudnienia, rentowności pomocy społecznej i stabilności finansowej systemów zabezpieczenia społecznego. Ponadto systemy podatkowe, które opierają się na dochodach z pracy, mogą być poddane silnej presji, ponieważ maszyny zastępujące pracę ludzką nie płaca podatków ani nie odprowadzają składek na systemy zabezpieczenia społecznego. Wreszcie, zmiany technologiczne moga powodować wzrost nierówności dochodowych w społeczeństwie i silniejszą polaryzację między właścicielami kapitału i siłą robocza, zwłaszcza w odniesieniu do pracowników o niższych kwalifikacjach.

Powszechna deklaracja praw człowieka stwierdza, że „każdy ma prawo do życia, wolności i bezpieczeństwa osobistego” oraz „prawo do odpowiedniego standardu życia, gwarantującego zdrowie i dobre samopoczucie jego i jego rodziny”. W odpowiedzi na to stwierdzenie wprowadzono ideę „dochodu podstawowego", który powinien być dochodem o charakterze bezwarunkowym, oferowanym wszystkim osobom we wszystkich krajach.

Celem artykułu jest analiza teoretyczna i empiryczna koncepcji bezwarunkowego dochodu podstawowego ze szczególnym uwzględnieniem genezy oraz skutków wprowadzenia tego mechanizmu. W tekście wykorzystano metodę badawczą opartą na studiach literaturowych z zakresu makroeko-

1 A. Don, Basic income: a radical idea enters the mainstream, Parliament of Australia, Research Paper Series 2016, November 18. 
nomii i polityki gospodarczej oraz metody statystyczno-opisowe na podstawie danych publikowanych przez Organizację Współpracy Gospodarczej i Rozwoju.

\section{ISTOTA BEZWARUNKOWEGO DOCHODU PODSTAWOWEGO}

Bezwarunkowym dochodem podstawowym (unconditional basic income UBI), określanym jako „dochód obywatela” lub „demogrant”, jest dochód bezwarunkowo przyznany wszystkim członkom społeczeństwa indywidualnie, bez konieczności świadczenia pracy. Jest to zatem forma zagwarantowania minimalnych dochodów obywatelom. Dochód podstawowy ma charakter bezwarunkowy odnoszący się do trzech obszarów. Po pierwsze, prawo do tego dochodu i jego poziom są niezależne od wielkości i struktury gospodarstw domowych. Po drugie, dochód bezwarunkowy jest wypłacany bez względu na dochody obywateli pochodzace z innych źródeł. Po trzecie, dochód ten jest przyznawany bez konieczności wykonywania jakiejkolwiek pracy przez beneficjenta tego dochodu. Dochód podstawowy jest świadczeniem o charakterze pieniężnym, wypłacanym w sposób regularny (miesięczny, kwartalny lub roczny) przez państwo. Jeżeli wysokość dochodu podstawowego osiąga poziom wystarczający do zaspokojenia podstawowych potrzeb, mówi się o pełnym dochodzie podstawowym, jeśli zaś jest od niego niższa, jest to częściowy dochód podstawowy ${ }^{2}$.

Zasadnicza idea wprowadzenie dochodu podstawowego jest, aby wszyscy obywatele, niezależnie od swoich dochodów indywidualnych, otrzymywali od państwa co miesiąc jednolite kwoty wystarczające do zaspokojenia swoich podstawowych potrzeb. W rezultacie wszystkie inne świadczenia społeczne finansowane przez państwo, takie jak zasiłki dla bezrobotnych lub świadczenia na dziecko, zostaja cofnięte. Tego rodzaju podstawowe dochody byłyby finansowane w dużej mierze przez wyeliminowanie kosztów, które w niektórych przypadkach wykazywały wysoce złożone świadczenia społeczne (w tym związane z nimi wydatki administracyjne).

Instrument ten, oprócz bezpośredniej wypłaty kwoty pieniężnej beneficjentom bezwarunkowego dochodu podstawowego, może przyjąć formę negatywnego podatku dochodowego (negative income tax - NIT). Negatywny podatek dochodowy występuje $\mathrm{w}$ połączeniu $\mathrm{z}$ istniejącym systemem podatku dochodowego o charakterze progresywnym. Ujemny podatek dochodowy wykorzystuje mechanizm, dzięki któremu zbierane są dochody podatkowe od osób o dochodach powyżej minimum, aby zapewnić pomoc finansową osobom o dochodach poniżej tego poziomu. Stąd od zobowiązań podatkowych poszczególnych gospodarstw domowych odejmuje się kwoty dochodu podstawowego przysługujące jego członkom. Jeżeli różnica ta jest dodatnia, to należy zapłacić podatek. Jeśli zaś różnica ta jest ujemna, państwo wypłaca świadczenie gospodarstwu domowemu.

${ }^{2}$ A. Fumagalli et al., Bezwarunkowy dochód podstawowy, „Praktyka Teoretyczna” 2014, nr 2(12). 
W rzeczywistości rozkład dochodów gospodarstw domowych osiagnięty dzięki bezwarunkowemu dochodowi podstawowemu i negatywnemu podatkowi dochodowemu jest taki sam. Pomimo pozornego podobieństwa wyżej wymienionych mechanizmów negatywny podatek dochodowy może okazać się mniej kosztownym rozwiązaniem. Sytuacja ta wynika z faktu, że w przypadku bezwarunkowego dochodu podstawowego następuja dwukierunkowe przepływy pieniężne, jeden wynikający z wypłacania podstawowego dochodu, a drugi - związany z płatnością podatku dochodowego. Natomiast w przypadku ujemnego podatku dochodowego występuje jedna płatność na rzecz gospodarstwa domowego. Z drugiej strony bezwarunkowy dochód podstawowy charakteryzuje się pewną przewagą nad negatywnym podatkiem dochodowym, która wynika z tego, że każdy wariant ujemnego podatku dochodowego wymaga uzupełnienia o system świadczeń zaliczkowych, zanim dojdzie do ostatecznego rozliczenia podatku na koniec roku fiskalnego. Ponadto, pomimo takiego samego rozkładu dochodu pomiędzy gospodarstwami domowymi, w przypadku bezwarunkowego dochodu podstawnego podział dochodów wewnątrz samych gospodarstw domowych jest bardziej równy niż w przypadku negatywnego podatku dochodowego. Wreszcie w przypadku bezwarunkowego dochodu podstawowego beneficjenci otrzymują stałych dochód niezależnie od tego, czy osiagaja dodatkowe dochody (np. z tytułu zatrudnienia), czy też nie osiagaja żadnych dochodów. Natomiast negatywny podatek dochodowy zależy od osiąganych dochodów przez członków gospodarstwa domowego ${ }^{3}$.

Inną formą dochodu podstawowego są suplementy wynagrodzeń, czyli dodatki do wynagrodzenia mające na celu zapewnienie dodatkowych dochodów, tak aby żaden pracownik nie zarobił mniej niż pewien poziom dochodu. Rząd $\mathrm{w}$ tym przypadku gwarantuje pokrycie różnicy między tym, co jednostka zarobiła, a ustalonym przez państwo minimum ${ }^{4}$.

Zarówno koncepcja dochodu podstawowego, jak również wskazywane sposoby jego dystrybucji między obywateli różnią się istotnie w zależności od doktryny ekonomicznej, z którą mamy do czynienia. Mianowicie, zgodnie z podejściem klasycznym (liberalnym) zwolennicy dochodu podstawowego postuluja wprowadzenie tej idei w postaci „negatywnego podatku dochodowego”. Zgodnie z tą doktryną funkcje państwa powinny zostać ograniczone do niezbędnego minimum - należy ustanowić negatywny podatek progresywny. Osoby znajdujące się poniżej określonego progu ubóstwa nie płaciłyby wówczas podatków dochodowych, a państwo wypłacałoby odpowiednie środki niezbędne do osiagnięcia przez każdą osobę tego progu. W tym przypadku usługi publiczne (szkoły, opieka zdrowotna itd.) byłyby odpłatne, a wyjątek stanowiłyby wymiar sprawiedliwości i obronna narodowa.

Z kolei zgodnie z doktryną socjaldemokratów niezbędne jest zapewnienie cią̧łości dochodu osobom bezrobotnym lub osobom, których dochód z pracy jest zbyt niski. W tym przypadku dochód gwarantowany powinien być przeznaczony wyłącznie dla osób pozostających bez odpowiedniego źródła dochodu.

${ }^{3}$ P. Van Parijs, A basic income for all, „Boston Review” 2000, October/November, s. 4-8.

${ }^{4} \mathrm{M}$. Tanner, The pros and cons of a guaranteed national income, „Policy Analysis” 2015, no. 773 , s. $2-3$. 
Tego rodzaju redystrybucja dochodu jest niezależna od podejmowanej aktywności i trwa dopóki beneficjent tego świadczenia znajduje się poniżej progu ubóstwa. Zatem ta koncepcja jest zbieżna z ideą płacy gwarantowanej.

Wreszcie zgodnie z trzecią doktryna prezentowana przez radykałów dochód podstawowy powinien być powszechny, bezwarunkowy i nieograniczony czasowo. Tego rodzaju świadczenie nie miałoby dyskryminującego charakteru i stanowiłoby ciagły zasiłek, niezależny od rzeczywistej aktywności zawodowej i zapewniający każdemu obywatelowi danego kraju lub regionu określony poziom życia.

\section{GENEZA BEZWARUNKOWEGO DOCHODU PODSTAWOWEGO}

Idea bezwarunkowego dochodu podstawowego sięga 1796 r., kiedy to angielski radykał Thomas Spence wysunął pierwszą spójną i dopracowana propozycję przyznania wszystkim mieszkańcom świadczenia o równej wysokości, bez żadnych warunków wstępnych. Kwoty te miały być przyznane wszystkim obywatelom w równej wysokości i wypłacane co kwartał. Środki te miały pochodzić z części dochodu uzyskiwanego przez całą wspólnotę z dzierżawy ziemi.

W XIX w. postulat wprowadzenia dochodu podstawowego został przyjęty przez ruchy radykalne i socjalistyczne. Wśród zwolenników tej koncepcji znaleźli się m.in. Charles Fourier i Joseph Charlier. Większą popularność i uznanie idea dochodu podstawowego uzyskała w pierwszej połowie XX w. Główną zasługę w tej mierze przypisuje się działalności Bertranda Russella oraz E. Mabel Milner i Dennisa Milnera, którzy wysunęli propozycję powszechnego dochodu mającego przyczynić się do rozwiązania problemu ubóstwa.

Pod koniec lat sześćdziesiątych i na początku lat siedemdziesiątych XX w. po raz kolejny pojawiło się zainteresowanie koncepcją bezwarunkowego dochodu podstawowego. W wyborach prezydenckich w Stanach Zjednoczonych w 1972 r. laureat Nagrody Nobla Joseph Tobin wezwał demokratycznego kandydata George'a McGoverna do zaproponowania idei bezwarunkowego dochodu podstawowego, podczas gdy inny noblista - Milton Friedman zaproponował kandydatowi Republikanów Richardowi Nixonowi realizację koncepcji negatywnego podatku dochodowego ${ }^{5}$.

Zgodnie z propozycją Tobina bezwarunkowy dochód podstawowy można przedstawić w formie arytmetycznej jako $t=x+25$, gdzie $t$ jest średnią stopa podatkowa (w procentach $\mathrm{PKB}$ ) niezbędną do sfinansowania planowanego dochodu podstawowego $(x)$, wyrażonego jako odsetek PKB na jednego mieszkańca. Uzasadnienie tego wyrażenia brzmi następująco: wypłaty dochodu podstawowego muszą być finansowane w perspektywie długoterminowej, a 25\% to przybliżony udział nakładów w PKB potrzebnych do sfinansowania wydatków

5 A. Fumagalli et al., op. cit. 
publicznych niezwiązanych z opieką społeczną (zdrowie, edukacja, administracja publiczna, dług publiczny, wydatki wojskowe itp. $)^{6}$.

W 1986 r. utworzono organizację Basic Income European Network (BIEN), której celem było popularyzowanie idei dochodu podstawowego; w 2004 r. organizacja ta zmieniła nazwę na Basic Income Earth Network, przekształcając się z sieci europejskiej w organizację o zasięgu globalnym. W 1988 r. ukazał się pierwszy numer czasopisma „Basic Income Studies” poświęconego w całości szczegółowym analizom idei dochodu podstawowego.

W ostatnich kilkudziesięciu latach wiele krajów i regionów na świecie wprowadziło w życie idee dochodu podstawowego w pełnej postaci lub też w formie pilotażowej. Na przykład stan Alaska utworzył w 1976 r. Stały Fundusz, aby zainwestować dochody ze sprzedaży ropy naftowej w uznaniu, że zasoby mineralne należały do mieszkańców Alaski. Od 1982 r. corocznie wypłacana była dywidenda z funduszu na rzecz wszystkich mieszkańców tego stanu. Jedynym kryterium otrzymania pomocy finansowej był wymóg dotyczący posiadania statusu rezydenta przez co najmniej jeden rok i dalszy zamiar pozostania rezydentem na Alasce. Dywidenda była obliczana corocznie na podstawie pięcioletniej średniej wyników inwestycyjnych Funduszu. Największa dywidenda w wysokości 3269 USD została wypłacona w 2008 r. i zawierała jednorazowa premię w wysokości 1200 USD w celu zrekompensowania mieszkańcom wysokich cen paliw. W 2012 r. dywidenda wyniosła 878 USD na osobę lub 3512 USD w przypadku czteroosobowej rodziny. Obecnie dywidenda ta wynosi 2000 USD rocznie na jednego mieszkańca i wykazuje corocznie tendencję wzrostowa. Wypłacana dywidenda odegrała istotna rolę w uczynieniu Alaski jednym ze stanów o najniższym ubóstwie w USA i z najmniejszymi nierównościami dochodowymi. Chociaż indywidualna dywidenda była relatywnie niewielka, to całkowite oddziaływanie na gospodarkę było znaczące, gdyż w 2009 r. siła nabywcza mieszkańców Alaski wzrosła o $900 \mathrm{mln}$ dolarów. Wyniki te były porównywalne z utworzeniem nowej gałęzi w gospodarce lub z powstaniem 10000 nowych miejsc pracy. Jednocześnie nie zaobserwowano oddziaływania wypłacanej dywidendy na rynek pracy.

W latach 1968 i 1978 przeprowadzono cztery eksperymenty dotyczace gwarantowanego dochodu obywatelom wybranych obszarów Stanów Zjednoczonych (New Jersey, Seattle, Denver, Karolina Północna, Iowa, Gary w stanie Indiana). Chociaż testowany system występował $\mathrm{w}$ postaci negatywnego podatku dochodowym, a nie gwarantowanego dochodu podstawowego, ze względu na podobieństwo obu systemów skutki również były podobne. Wyniki eksperymentu ujawniły, że mężczyźni otrzymujący dochód ograniczyli swój czas pracy średnio o 7\%, a kobiety o 17\%. Wynikało to głównie ze zmniejszenia liczby przepracowanych godzin, a nie z całkowitej rezygnacji z pracy. Miesięczne wydatki obywateli wzrosły w umiarkowanym stopniu wraz ze wzrostem dochodów, lecz struktura tych wydatków nie zmieniła się zasadniczo ${ }^{7}$.

${ }^{6} \mathrm{~J}$. Kay, The basics of basic income, „Intereconomics” 52(2), 2017, s. 69-74.

7 A.H. Munnell, Lessons from the Income Maintenance Experiments: An Overview, Federal Reserve Bank of Boston Conference Series 1986, 30. 
W 2008 r. organizacja pozarządowa ReCivitas wprowadziła projekt pilotażowy wypłacania dochodów podstawowych w małym miasteczku Quatinga Velho położonym w pobliżu Sao Paulo w Brazylii. Projekt finansowany był z prywatnych darowizn i przewidywał comiesięczną wypłatę bezwarunkowego dochodu 27 osobom w kwocie 13,6 USD na mieszkańca. W ciagu trzech kolejnych lat liczba osób otrzymujących płatności wzrosła do 100. Wypłacana miesięcznie kwota dochodu bezwarunkowego była znacznie poniżej granicy ubóstwa, ale nawet mieszkańcy wioski otrzymujący podstawowe dochody wykazali poprawę zdolności do zaspokojenia podstawowych potrzeb. Naukowcy odnotowali poprawę jakości odżywiania wśród mieszkańców, przy czym 25\% podstawowego dochodu przeznaczano na wydatki na żywność. Nastapiła poprawa w zakresie stanu zdrowia i warunków życia. Pieniądze służyły również tworzeniu przez mieszkańców mikroprzedsiębiorstw ${ }^{8}$.

W styczniu 2013 r. uruchomiona została roczna procedura zbierania podpisów pod Europejską Inicjatywą Obywatelską na rzecz Dochodu Podstawowego. Celem inicjatywy było zobowiązanie Komisji Europejskiej do zachęcania państw członkowskich do współpracy w celu podjęcia badań nad dochodem podstawowym jako narzędziem naprawy ich systemów zabezpieczenia społecznego. Nie zakończyła się ona jednak sukcesem, gdyż z wymaganego miliona podpisów zdołano zebrać jedynie 285 tys. Zaledwie w sześciu krajach (Bułgarii, Słowenii, Chorwacji, Belgii, Estonii i Holandii) udało się zebrać minimalną wymaganą liczbę podpisów, a wyznaczony wcześniej cel został osiagnięty jedynie w Bułgarii. Zwolennicy koncepcji dochodu podstawowego zdecydowali, że związany z nią ruch społeczny powinien uzyskać instytucjonalną formę i założyli w 2014 r. organizację Unconditional Basic Income Europe.

W 2016 r. w Szwajcarii odbyło się ogólnokrajowe referendum, którego przedmiotem była chęć wprowadzenia dochodu podstawowego. Wyniki referendum pokazały, że prawie 77\% mieszkańców Szwajcarii sprzeciwiło się takiemu planowi, a poparło go tylko 23\%. Propozycja dochodu podstawowego skierowana była do osób dorosłych i dzieci. Mieli oni otrzymywać bezwarunkowe dochody miesięczne bez względu na swój status społeczny i zawodowy. Miesięczne dochody wypłacane przez państwo miały wynosić w przypadku osób dorosłych $2500 \mathrm{CH}$, a w przypadku dzieci $625 \mathrm{CH}$. Kwoty te odzwierciedlały wysokie koszty utrzymania w Szwajcarii. Szwajcaria jest pierwszym krajem na świecie, w którym odrzucono propozycję wprowadzenia bezwarunkowego dochodu podstawowego.

Również wprowadzony w 2016 r. w Polsce program Rodzina 500+ można by określić jako quasi-dochód gwarantowany, gdyby wypłacany był na każde dziecko, niezależnie od uzyskiwanych dochodów przez gospodarstwo domowe. Program Rodzina 500 plus to 500 zł miesięcznie wypłacane przez państwo na drugie i kolejne dziecko niezależnie od dochodu. Rodziny o niskich dochodach otrzymuja wsparcie także dla pierwszego lub jedynego dziecka przy spełnieniu kryterium przeciętnego miesięcznego dochodu 800 zł netto lub $1200 \mathrm{zl}$ w przypadku wychowywania w rodzinie dziecka niepełnosprawnego. Do końca

${ }^{2}$ Ch. Pasma, Basic Income Programs and Pilots, Basic Income Canada Network, 2014, February 3. 
2016 r. uprawnionych do otrzymywania wparcia było $3,8 \mathrm{mln}$ dzieci, co stanowiło 55\% wszystkich dzieci w wieku do 18 roku życia. Dzięki programowi podniósł się standard życia rodzin otrzymujacych świadczenie. Program przyniósł zdecydowaną poprawę warunków materialnych rodzin, skutkująca zmniejszeniem liczby osób korzystających ze świadczeń pomocy społecznej i z pomocy w postaci dożywiania. Dzięki programowi ubóstwo ogółem zmniejszyło się o $48 \%$, a ubóstwo skrajne o $-98 \%{ }^{9}$.

Najbardziej zaawansowanymi doświadczeniami w odniesieniu do dochodu podstawowego może pochwalić się Finlandia, gdzie w 2017 r. wypłacono 2 mln obywateli świadczenia z tytułu bezrobocia w wysokości 560 euro miesięcznie, co odpowiada jednej czwartej średniego dochodu gospodarstw domowych w Finlandii. W tym przypadku dochód podstawowy nie wyeliminował dodatkowych świadczeń dla obywateli (np. świadczenie mieszkaniowe) ani nie doprowadził do zmian w zakresie podatków dla osób otrzymujących dochody podstawowe.

\section{SKUTKI WPROWADZENIA BEZWARUNKOWEGO DOCHODU PODSTAWOWEGO}

W literaturze ekonomicznej wskazuje się wymierne korzyści wynikające z wprowadzenia bezwarunkowego dochodu podstawowego. Po pierwsze, bezwarunkowy dochód podstawowy umożliwia obywatelom swobodę wydawania pieniędzy w pożądany przez nich sposób. Innymi słowy, dochód podstawowy wzmacnia wolność gospodarczą na poziomie jednostki. Dochód ten zapewnia mieszkańcom swobodę wyboru konkretnego rodzaju pracy zamiast zmuszania ich do nieproduktywnych prac w celu zaspokojenia ich codziennych potrzeb. Po drugie, dochód podstawowy stanowi swego rodzaju ubezpieczenie na wypadek bezrobocia i tym samym może przyczynić się do ograniczenia ubóstwa. Po trzecie, dochód podstawowy prowadzi do sprawiedliwej dystrybucji bogactwa. Po czwarte, wzrost dochodów zwiększa siłę przetargową obywateli, ponieważ nie sa już oni zmuszeni do zaakceptowania oferowanych warunków pracy. Po piąte, dochód bezwarunkowy jest łatwy w implementacji. Ze względu na swój uniwersalny charakter nie ma potrzeby identyfikowania beneficjentów. Wyklucza zatem błędy w identyfikacji planowanych beneficjentów, co jest częstym problemem w ukierunkowanych programach socjalnych. Po szóste, z względu na fakt, że każda jednostka otrzymuje podstawowe dochody, promuje się w ten sposób efektywność, redukując straty w transferach rządowych. Po siódme, bezpośredni transfer bezwarunkowych dochodów do obywateli może przyczynić się do ograniczenia korupcji w kraju. Po ósme, osiagane korzyści moga wynikać ze zmniejszenia kosztów i czasu w wyniku zastapienia przez dochód podstawowy wielu programów społecznych. Wreszcie po dziewiąte, transfery podstawowych dochodów bezpośrednio na rachunki bankowe odbiorców moga

9 Zob. <https://www.mpips.gov.pl> [dostęp: 4.10.2017]. 
zwiększyć popyt na usługi finansowe, co sprzyja rozwojowi rynku finansowego w kraju ${ }^{10}$.

Natomiast przeciwnicy koncepcji bezwarunkowego dochodu podstawowego wskazuja na następujące wady tego systemu. Przede wszystkim jest to ryzyko hazardu moralnego. Konsekwencją tego jest ograniczenie motywacji do pracy i w ślad za tym spadek podaży siły roboczej w kraju. Ponadto chodzi o koszty fiskalne i ryzyko spadku siły nabywczej transferów otrzymywanych przez obywateli. Mianowicie przeciwnicy koncepcji bezwarunkowego dochodu twierdza, że po wprowadzeniu dochodu bezwarunkowego rosną podatki w kraju w celu sfinansowania rosnacych wydatków rządowych. Co więcej, wzrost podaży pieniądza w kraju może spowodować w nim wzrost inflacji i spadek siły nabywczej.

Oczywiste jest, że nie można jednoznacznie określić wpływu dochodu podstawowego na cały rynek, dochód ten bowiem oddziałuje na poszczególne obszary funkcjonowania życia gospodarczego, przy czym w niektórych przypadkach wpływ ten jest pozytywny, a w innych negatywny ${ }^{11}$. Wpływ wprowadzenia bezwarunkowego dochodu podstawowego na pracodawców może być pozytywny w odniesieniu do miejsc pracy, które stymulują konkurencyjność pracowników. Bez konieczności wykonywania pracy w celu zapewnienia określonego poziomu życia jednostki mogą rozwijać się i poszukiwać takiego zatrudnienia, które da im satysfakcję i możliwość poczucia spełnienia. Rosnaca konkurencja przyciagnie na rynek pracy osoby lepiej przygotowane, które chętniej będą się uczyć i rozwijać, a zatem nastapi silny rozwój zasobów ludzkich. Ponadto stała ochrona socjalna i wzrost podaży pracy na rynku pozwola pracodawcom na obniżenie płac. Niemniej jednak istnieje duże zagrożenie dla pracodawców oferujących pracę osobom o mniejszych kwalifikacjach. W tym przypadku w celu wypełnienia wolnych wakatów pracodawca będzie musiał zapłacić wyższe wynagrodzenie. Wzrost funduszu płac doprowadzi do wyższych cen, wzrost cen zaś pociagnie za sobą konieczność zwiększenia bezwarunkowego dochodu podstawowego.

Również wpływ wprowadzenia bezwarunkowego dochodu podstawowego na pracowników jest pozytywny. Otrzymując bezwarunkowe dochody, są oni w stanie realizować własny, ciagły rozwój i angażować się w programy, które pomogą im zdobyć pożądane pozycje i są w stanie zainwestować część dochodu podstawowego w edukację bez wpływu na budżet rodziny.

Dominujacy obecnie na świecie podatek dochodowy o charakterze progresywnym wydaje się najlepszym, dostępnym źródłem finansowania polityki społecznej, która dąży do zagwarantowania odpowiedniego standardu życia obywatelom przez wprowadzenie bezwarunkowego dochodu podstawowego. Wprowadzeniu dochodu podstawowego musi towarzyszyć organicznie lub wręcz całkowite wyeliminowanie innych form pomocy społecznej, jak np. zasiłków dla osób bezrobotnych, emerytur, dodatków socjalnych, i pozostawienie tylko funduszy przeznaczonych dla osób niepełnosprawnych. Ponadto wpro-

${ }^{10}$ Universal Basic Income (UBI): Everything you need to know, <http://www.clearias.com>.

11 J. Sattelberger, Unconditional basic income: an instrument for reducing inequality?, „KfW Development Research', Development in Brief 2016, 39. 
wadzenie bezwarunkowego dochodu podstawowego może przyczynić się do zmniejszenia wydatków z budżetu państwa w wyniku spadku zatrudnienia w sektorze publicznym. Z drugiej strony wyeliminowanie składek na ubezpieczenie od bezrobocia i składek na ubezpieczenie społeczne może doprowadzić do ograniczenia presji fiskalnej w gospodarce ${ }^{12}$.

\section{BEZWARUNKOWY DOCHÓD PODSTAWOWY W ŚWIETLE WYNIKÓW ANALIZ EMPIRYCZNYCH}

Organizacja Współpracy Gospodarczej i Rozwoju (OECD) w opublikowanym raporcie stwierdziła, że w przypadku większości krajów o wysokich dochodach bezwarunkowy dochód podstawowy może w rzeczywistości zwiększyć ubóstwo. Ogłoszony wniosek opiera się na analizie scenariusza, w którym wszystkie istniejące świadczenia pieniężne i podatkowe dla osób poniżej 65 roku życia zostają zastapione przez bezwarunkowy dochód podstawowy w 35 krajach członkowskich OECD. Analiza przeprowadzona przez tę organizację pokazuje, że rządy w większości krajów członkowskich realizuja programy wsparcia społecznego na rzecz osób ubogich, bezwarunkowy dochód podstawowy zaś uczyni to mniej precyzyjnie. OECD przeprowadziła szczegółową analizę wpływu bezwarunkowego dochodu podstawowego na cztery kraje członkowskie: Finlandię, Francję, Włochy i Wielką Brytanię. W trzech z czterech analizowanych krajów stwierdzono, że ich hipotetyczny dochód bezwarunkowy rzeczywiście zwiększyłby poziom ubóstwa o co najmniej $1 \%{ }^{13}$.

Rabin Jessen i Davud Rostam-Afschar przeprowadzili badania empiryczne dotyczące potencjalnych efektów wprowadzenia bezwarunkowego dochodu podstawowego w Niemczech na poziomie 800 euro miesięcznie dla osób dorosłych i 380 euro miesięcznie dla osób poniżej 18 lat. Kwoty te są bliskie obecnemu poziomowi egzystencji gwarantowanemu przez zasiłki dla bezrobotnych i pomoc społeczną w Niemczech. W badaniu założono, że mechanizm ten jest finansowany z podatku liniowego o stawce $68,9 \%$. Autorzy badań stwierdzili, że wprowadzona reforma zwiększyłaby podaż siły roboczej w Niemczech w pierwszym decylu dystrybucji dochodów. Efekt ten byłby istotny i oznaczałby wzrost podaży pracy tej grupy o $6,1 \%$. Z drugiej strony wprowadzenie bezwarunkowego dochodu podstawowego w Niemczech zmniejszyłoby podaż siły roboczej w większości pozostałych decyli dochodów. Generalnie rzecz ujmując, wprowadzenie bezwarunkowego dochodu podstawowego zmniejszyłoby całkowita podaż pracy o 5,2\%. Korzystając z utylitarnej funkcji pomocy społecznej, autorzy badań potwierdzili, że łączne korzyści społeczne możliwe do osiagnięcia byłyby wyższe w porównaniu z obecną sytuacja. Wyniki analizy

${ }_{12}$ O.A. Cercelaru, Unconditional basic income - impact on the economy, „Annals of the Constantin Brâncuşi” 3, 2016, s. 120-121.

${ }^{13}$ Basic Income as a Policy Option: Can it Add Up?, Organization for Economic Cooperation and Development, 2017, May. 
potwierdziły zatem, że wprowadzenie bezwarunkowego dochodu podstawowego w Niemczech byłoby ekonomicznie uzasadnione, zwiększyłoby motywację do pracy w biedniejszych gospodarstwach domowych i przyniosłoby korzyści socjalne w porównaniu z obecnie obowiązującym systemem.

Organizacja Narodów Zjednoczonych do spraw Oświaty, Nauki i Kultury (UNICEF) zakończyła kilka lat temu projekt pilotażowy we współpracy z Samorządowym Stowarzyszeniem Kobiet (SEWA) w Indiach, majacy na celu analizę efektywności bezwarunkowego dochodu podstawowego wśród tysięcy mieszkańców wioski w stanie Madhya Pradesh. Wyniki badań potwierdziły wzrost lokalnej aktywności gospodarczej przejawiającej się powstawaniem mikroprzedsiębiorstw, tworzeniem nowych miejsc pracy, a także rosnącymi zakupami urządzeń technicznych i zwierząt gospodarskich dla lokalnej społeczności. Ponadto osoby otrzymujace bezwarunkowy dochód podstawowy odnotowały istotna poprawę w odżywieniu dzieci, skolaryzacji dzieci, opieki zdrowotnej i zakwaterowania. Należy również zaznaczyć, że wzrost korzyści osiaganych przez kobiety był większy niż w przypadku mężczyzn (zwiększenie autonomii finansowej kobiet), większy w przypadku osób niepełnosprawnych w porównaniu z osobami zdrowymi, a także większy wśród osób najbiedniejszych niż zamożnych ${ }^{14}$.

Stosunkowo niewielu ekonomistów twierdzi, że wszyscy obywatele moga korzystać w wyniku wprowadzenia dochodu podstawowego ${ }^{15}$. Zdaniem Etienne'a Lehmanna ostateczny skutek wprowadzenia dochodu podstawowego zależy od poziom wykształcenia w kraju. Twierdzi on, że bardziej wykwalifikowane osoby osiagają znacznie mniejsze korzyści z dochodu podstawowego niż osoby mniej wykwalifikowane ${ }^{16}$.

Z kolei Derek Hum i Wayne Simpson, odnosząc się do eksperymentów, które przeprowadzonych w latach siedemdziesiątych XX w. w Manitobie (Kanada), przyznali, że redukcja zatrudnienia po wprowadzeniu bezwarunkowego dochodu podstawowego była stosunkowo niewielka (ok. 1\% w przypadku mężczyzn, 3\% - zamężnych kobiet i 5\% - niezamężnych kobiet). Ponadto badacze zauważyli, że wprowadzenie bezwarunkowego dochodu podstawowego miało istotny wpływ na strukture gospodarstw domowych ${ }^{17}$.

$\mathrm{Na}$ podstawie przeprowadzonych badań empirycznych dotyczących koncepcji bezwarunkowego dochodu podstawowego można wyciagnać dwa główne wnioski. Po pierwsze, dochód podstawowy wykazuje generalnie pozytywne efekty tylko wtedy, gdy nie jest zbyt wysoki lub znajduje się nieco poniżej progu względnego ubóstwa. Po drugie, dochód podstawowy powinien zastępować zasiłki dla osób bezrobotnych.

14 S. Davala et al., Basic Income: A Transformative Policy for India, Bloomsbury Academic, London-New York 2015.

${ }^{15}$ A. Chéron, Allocation universelle vs. indemnité chômage. Evaluation quantitative dans un modèle d'appariement, „Revue Économique” 53(5), 2002.

16 E. Lehmann, Évaluation de la mise en place d'un système d'allocation universelle en présence de qualifications hétérogènes: le rôle institutionnel du salaire minimum, „Économie et Prévision” 157(1), 2003.

17 D. Hum, W. Simpson, A guaranteed annual income? From mincome to the millennium, „Policy Options” 2001, January/February. 


\section{ZAKOŃCZENIE}

Zwolennicy wprowadzenia bezwarunkowego dochodu podstawowego twierdzą, że przyczyni się on do ograniczenia możliwości nadużywania systemu. Bezwarunkowe przekazywanie podstawowych dochodów jest bardzo prostym i przejrzystym systemem transferowym, który drastycznie zmniejsza możliwości nadużyć $\mathrm{w}$ porównaniu z innymi systemami powszechnie stosowanymi obecnie. Ponadto wprowadzenie dochodu podstawowego zmniejsza stygmatyzację wnioskodawców. Jednocześnie zwolennicy twierdzą że tworzy bardziej egalitarne społeczeństwo i otwiera możliwości indywidualnej samorealizacji. Co więcej, zwolennicy podstawowego dochodu twierdza, że rozwój technologiczny w świecie pracy powoduje, że rozwiązania techniczne stale zastępuja pracę ręczną. Oznacza to, że niewielka grupa osób o wysokich zarobkach stanie w obliczu rosnącej liczby bezrobotnych. Bezwarunkowy dochód podstawowy zapewni wówczas konieczną równowagę społeczną.

Natomiast przeciwnicy wprowadzenia bezwarunkowego dochodu podstawowego twierdza, że wiara $\mathrm{w}$ równe rozprowadzanie podstawowego dochodu jest tylko pobożnym życzeniem i że nigdy nie może to stać się rzeczywistością. Ponadto dochód bezwarunkowy rodzi ryzyko nadużycia (hazardu moralnego), dochód podstawowy bowiem zmniejszyłby istotnie skłonność do podejmowania pracy i tym samym doprowadziłby do spadku zatrudnienia. Spowodowałoby to ograniczenie sił napędowych gospodarki rynkowej. Dodatkowo wprowadzenie dochodu podstawowego spowodowałoby utrate innych świadczeń socjalnych i tym samym konieczność samofinansowania potrzeb socjalnych.

Bezwarunkowy dochód podstawowy stanowi w rzeczywistości radykalna zmianę systemu społecznego, jest przy tym sprawiedliwy, liberalny i traktuje wszystkich obywateli jednakowo. Osoby o wyższych dochodach płaca więcej podatków niż osoby o niższym dochodach w ujęciu absolutnym i względnym. Dochód zapewniajacy minimum egzystencji gwarantowany jest wszystkim, a osoby bez dochodów otrzymuja transfery netto. Mimo że koncepcja bezwarunkowego dochodu gwarantowanego nie jest doskonała ani tania w realizacji, wydaje się zasadne przynajmniej rozważenie radykalnej zmiany obecnego systemu pomocy społecznej. Niekiedy bowiem okazuje się, że ryzyko radykalnych zmian jest mniejsze niż ryzyko związane z kontynuacją istniejącego systemu, ponieważ obecny system socjalny może nasilać presję społeczną i polityczną w wyniku rosnącej polaryzacji społeczeństwa.

dr hab. Piotr Misztal

Profesor Uniwersytetu Jana Kochanowskiego w Kielcach

pmisztal@ujk.edu.pl 


\section{THE UNCONDITIONAL BASIC INCOME \\ AS AN INSTRUMENT FOR REDUCING INCOME INEQUALITIES}

\section{Sum mary}

The unconditional basic income is the income allotted to all members of society individually, without them having to provide work instead. The right to this income and its level are unconditional and independent of the size and structure of households. In addition, unconditional income is paid regardless of the citizens' income from other sources. The aim of this paper was to conduct a theoretical and empirical analysis of the unconditional basic income, with particular emphasis on the genesis and effects of the implementation of such a mechanism. The research methods used in the paper have been based on literature presenting studies in macroeconomics and economic policy as well as on the data obtained using statistical and descriptive methods published by the Organisation for Economic Co-operation and Development.

\section{Aneks}

Proponowana wysokość dochodu podstawowego w wybranych krajach i regionach
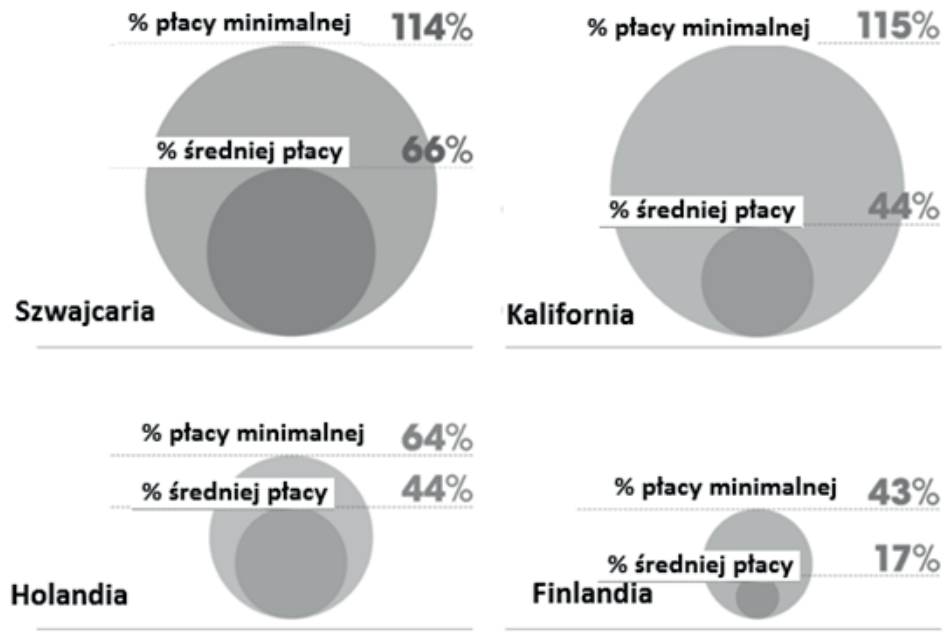

Źródło: <https://apolitical.co>. 